\title{
Developmental expression of the lipoprotein lipase gene in porcine subcutaneous adipose tissue ${ }^{*}$
}

\author{
T.Z. Shan, Y.Z. Wang ${ }^{1}$, Y.J. Liu, J.X. Liu, J. Feng and Z.R. Xu \\ Institute of Feed Science, Zhejiang University, \\ The Key Laboratory of Molecular Animal Nutrition, Ministry of Education \\ No. 164 Qiutao North Road, Hangzhou 310029, P.R. China
}

(Received 11 April 2006; revised version 17 July 2006; accepted 6 November 2006)

\begin{abstract}
Lipoprotein lipase (LPL) has been implicated as a key enzyme in lipid metabolism. The pattern of LPL gene expression in different ages and its relation to adipose deposition was studied. Fifteen female Duroc $\times$ Landrace $\times$ Yorkshire pigs aged at 1 day, 7, 14, 21 and 28 weeks (three pigs per age, $10 \%$ per each bred) were used to study developmental gene expression of LPL in subcutaneous adipose tissue by means of semi-quantitative RT-PCR. The results showed that the LPL mRNA levels in subcutaneous adipose tissue significantly increased from 1 day to 7 weeks $(P<0.01)$, and then gradually decreased from 7 to 28 weeks. A strong inverse correlation between LPL mRNA levels and age as well as adipose index and body weight was found between 7 and 28 weeks. Body weight and total adipose weight increased significantly with age $(\mathrm{P}<0.01)$.
\end{abstract}

KEY WORDS: lipoprotein lipase, gene expression, fat deposition, pig

\section{INTRODUCTION}

Aging in mammals is associated with a number of changes in body composition, such as a relative increase in body adiposity and a reduction in lean body mass (Imbeault et al., 2000). Previous study had proved that the fat content of the carcass was significantly correlated with animal age (Souza et al., 2004). However, the precise mechanisms of the age-related changes are mostly unknown. It is well known that lipoprotein lipase is a key enzyme in lipid metabolism (Maingrette and Renier, 2003), which is produced in adipose tissue and other tissues, including the

\footnotetext{
* Supported by the fund of National Basic Research Program (973), No. 2004 CB117506

${ }^{1}$ Corresponding author: e-mail: yzwang@zju.edu.cn
} 
heart and skeletal muscle, nervous system, liver, adrenals, macrophages, proximal tubules of the kidneys, pancreatic islet cells, and lungs (Merkel et al., 2002). LPL controls triacylglycerol partitioning between adipose tissues and muscles, thereby affecting fat storage or providing energy in the form of fatty acids for muscle growth (Hocquette et al., 1998). For this reason, the study of LPL is of particular interest in improving meat quality.

Several studies have proved that LPL activity and mRNA level were affected by age in the adipose tissue of rat and rhesus monkeys (Ursini et al., 1991; Hotta et al., 1999). In pigs, previous studies of LPL regulation during aging have focused on the enzyme activity measurements (Mersmann, 1998). There were no data about the effect of age on the porcine LPL gene expression in adipose tissue.

The purpose of the present study was to investigate the effects of age on the LPL gene expression in subcutaneous adipose tissue and its relation to adipose deposition and body weight to obtain information for improving meat production quality.

\section{MATERIAL AND METHODS}

\section{Animals}

All the experiments were done according to the guidelines for animal experiments at the National Institute of Animal Health. A total of fifteen female pigs (Duroc $\times$ Landrace $\times$ Yorkshire) aged 1 day, 7, 14, 21 and 28 weeks (three pigs per age, 10\% per each bred) were weighted and euthanized under anaesthesia after a $12 \mathrm{~h}$ fast and $\mathrm{ad}$ libitum access to water. Subcutaneous adipose tissue was dissected and rapidly frozen in liquid nitrogen, then stored at $-80^{\circ} \mathrm{C}$ until RNA analysis for determination of LPL gene expression. Peritoneal adipose tissue (PAT), subcutaneous adipose tissue (SAT) and omental adipose tissue (OAT) in left-half carcasses were collected and weighed for the adipose deposition. The adipose deposition was determined by the adiposity index expressed as the sum of the weight of PAT, SAT and OAT divided by body weight $\times 100$ (Taylor et al., 1996; Nogalska and Swierczynski, 2001).

\section{Total RNA extraction}

Total RNA was isolated from subcutaneous adipose tissue at the indicated times using Trizol Reagent (Invitrogen Life Technologies, Carlsbad, CA, USA) according to the manufacturer's instructions. After pulverization and homogenization of the tissue, RNA was extracted from the homogenate with chloroform and then precipitated by isopropanol. The resulting pellets were dissolved in ultrapure water and the quantity and the quality of total RNA were measured by a spectrophotometer 
at 260 and $280 \mathrm{~nm}$. The 260/280 ratio is at least 1.7 (high quality RNA gives a ratio of 2.0) otherwise the concentration readings will not be accurate. In this experiment, the range of 260/280 ratio was about $1.8 \sim 2.0$.

\section{Reverse transcription}

Two micrograms of total RNA and $2 \mu \mathrm{l}$ of random primers $(500 \mu \mathrm{g} / \mathrm{ml}$, Promega Corporation, Madison, WI, USA) were denatured at $70^{\circ} \mathrm{C}$ for $5 \mathrm{~min}$. The following components were added in order: $5 \mu 1$ M-MLV $5 \times$ Reaction Buffer $(250 \mathrm{mM}$ Tris$\mathrm{HCl}, \mathrm{pH} 8.3 ; 375 \mathrm{mM} \mathrm{KCl} ; 15 \mathrm{mM} \mathrm{MgCl} ; 50 \mathrm{mM}$ dithiothreitol), $2 \mu \mathrm{dNTP}$ mix (10 mM each of dATP, dCTP, dGTP and dTTP), $1 \mu \mathrm{l}$ M-MLV reverse transcriptase (200 U/ $\mu \mathrm{l}$, Promega), $0.5 \mu \mathrm{l}$ RNasin ribonuclease inhibitor, and nuclease-free water to a final volume of $25 \mu \mathrm{l}$. It was mixed gently by flicking the tube, and the reaction mixture was incubated at $37^{\circ} \mathrm{C}$ for $60 \mathrm{~min}$.

\section{RT-PCR assay}

One microliter of reverse-transcribed cDNA was used as the template for PCR amplification in a total volume of $50 \mu$ l. Oligonucleotide primers (ShangHai Sangon Biological Engineering Technology and Service Company) specific for porcine LPL and 18S rRNA were based on known sequences deposited in Genbank and are listed in Table 1. The optimum PCR primer concentration, $\mathrm{Mg}^{2+}$ concentration, cycles and annealing temperature that would result in linear amplification of each transcript was determined by a preliminary experiment (data not shown). The PCR assay mixture contained the following components: $37.5 \mu \mathrm{l}$ nuclease-free water, $5 \mu \mathrm{l} 10 \times \mathrm{PCR}$ reaction buffer, $3 \mu \mathrm{IgCl}_{2}(25 \mu \mathrm{M}), 1 \mu \mathrm{dNTP}$ mix $(10 \mathrm{mM}$ each of dATP, dCTP, dGTP and dTTP), $1 \mu \mathrm{l}$ sense primer $(20 \mu \mathrm{M}), 1 \mu \mathrm{l}$ antisense primer $(20 \mu \mathrm{M})$ and $0.5 \mu \mathrm{l}$ Taq DNA polymerase (2 U/ $\mu$ l, Promega). All subsequent amplification reaction steps were performed using a GeneAmp® PCR System 9600 (Perkin-Elmer, Fremont, CA, USA). The PCR profiles for LPL and $18 \mathrm{~S}$ rRNA consisted of denaturation at $94^{\circ} \mathrm{C}$

Table 1. Specific primers of LPL, leptin, and 18S rRNA gene

\begin{tabular}{|c|c|c|c|c|}
\hline Gene & $\begin{array}{l}\text { Accession } \\
\text { number }\end{array}$ & $\begin{array}{l}\text { Primer } \\
\text { source }\end{array}$ & Oligonucleotide sequence & $\begin{array}{c}\text { Length } \\
\text { bp }\end{array}$ \\
\hline LPL & AY686761 & Pig & $\begin{array}{l}\text { 5'- CAGGGTGTAACATTGGGGAA-3' } \\
\text { (sense primer) } \\
\text { 5'-CAGAGACTTGTCGTGGCATTT-3' } \\
\text { (antisense primer) }\end{array}$ & 689 \\
\hline 18S rRNA & AY265350 & Pig & $\begin{array}{l}\text { 5' - CTCCACCAACTAAGAACGG - 3' } \\
\text { (sense primer) } \\
\text { 5' - AAGACGGACAGAGCGAAA-3' } \\
\text { (antisense primer) }\end{array}$ & 375 \\
\hline
\end{tabular}


for $2 \mathrm{~min}$, followed by 29 cycles of amplification at $94^{\circ} \mathrm{C}$ for $45 \mathrm{~s}, 53^{\circ} \mathrm{C}$ for $45 \mathrm{~s}$, and extension at $72^{\circ} \mathrm{C}$ for $50 \mathrm{~s}$, and followed by a final extension at $72^{\circ} \mathrm{C}$ for $10 \mathrm{~min}$.

The expression of porcine LPL mRNA was determined by the semi-quantitative RT-PCR method (Marone et al., 2001) using the housekeeping gene 18S rRNA as an inner control. PCR products were electrophoresed on $1.0 \%(\mathrm{w} / \mathrm{v})$ agarose gel and the electrophoresis band intensities were quantified using Image Master VDS software (Amersham Pharmacia Biotech, Uppsala, Sweden). Mean LPL mRNA levels normalized against $18 \mathrm{~S}$ rRNA levels from adipose tissue were presented in absolute integrated optical density.

\section{Statistical analysis}

All the data were analysed statistically according to the ANOVA procedure (SAS Institute, 1989) and the treatment means were separated by Duncan's multiple range test. Statistical significance was at $\mathrm{P}<0.05$ for all statistical tests.

\section{RESULTS}

The body weight and adiposity deposition

The pigs, under ad libitum feeding conditions, demonstrated a progressive increase in body weight with age between 1 day and 28 weeks (Figure $1 ; \mathrm{P}<0.01$ ). The weight of omental, peritoneal, and subcutaneous adipose tissues in these pigs

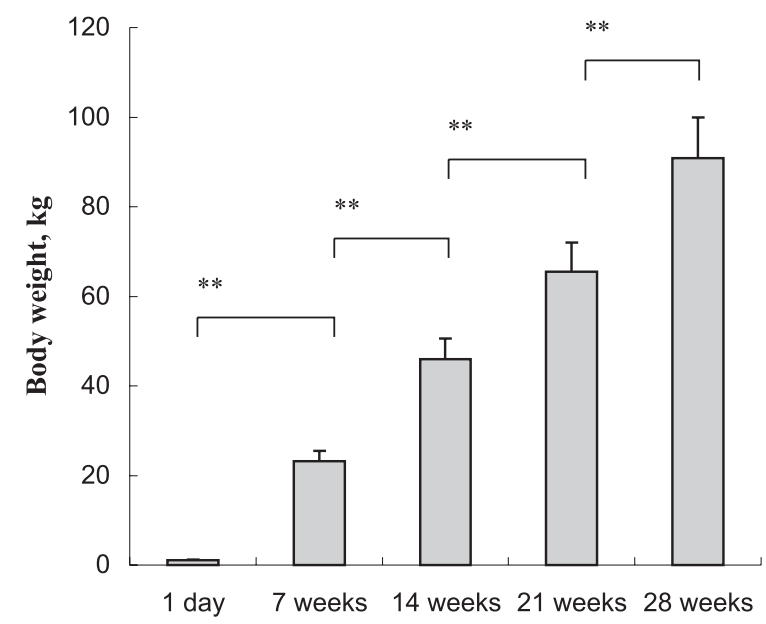

Figure 1. Body weight of pigs at ages 1 day, 7, 14, 21 and 28 weeks. Data represent means \pm SD of three pigs per age. $* * \mathrm{P}<0.01$ 


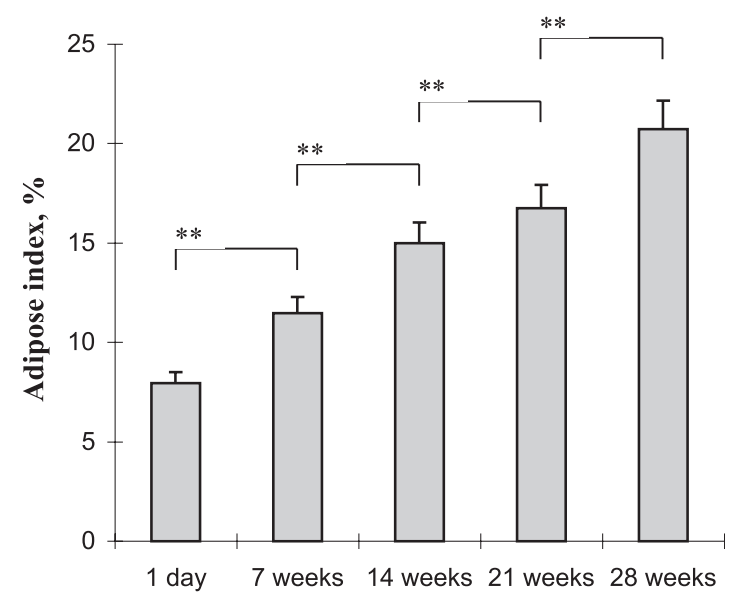

Figure 2. Adiposity index in pigs at ages 1 day, 7, 14, 21 and 28 weeks. Each column is the mean $( \pm \mathrm{SD})$ of three pigs per age. ${ }^{* *} \mathrm{P}<0.01$

significantly increased with age (data not shown). Consequently the adiposity index increased significantly $(\mathrm{P}<0.01)$ at all stages studied (Figure 2$)$. Additionally, a strong positive correlation between age and adipose deposition $(\mathrm{r}=0.98, \mathrm{P}<0.01)$ as well as body weight was found in pigs between 1 day and 28 weeks.

\section{Developmental gene expression of LPL in subcutaneous adipose tissue}

The developmental expression of LPL gene in porcine subcutaneous adipose tissue at different ages was evaluated using semi-quantitative RT-PCR. The

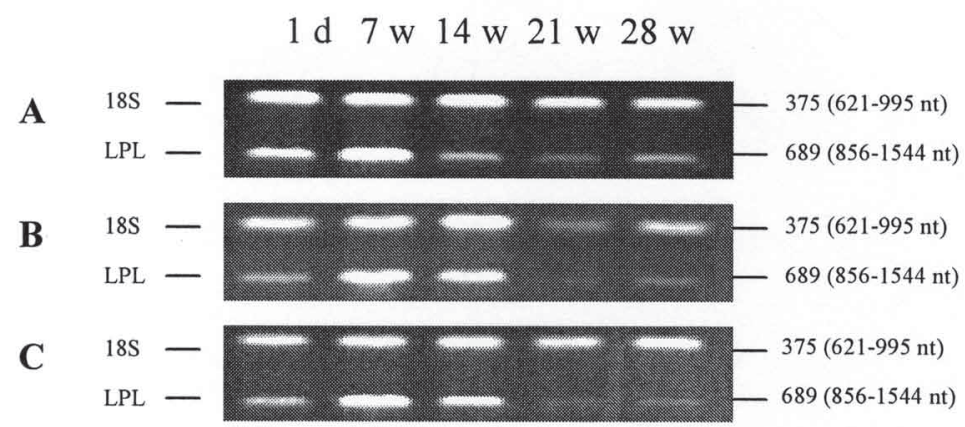

Figure 3. Electrophoresis of RT-PCR products for LPL and 18S rRNA(18S) genes in the subcutaneous adipose tissue of pigs aged at 1 day, 7, 14, 21 and 28 weeks. The PCR amplification products from mRNA were 689 (856-1544 nt) and 375 (621-995 nt) bp for LPL and 18S rRNA. A, B, C were three repetitions 


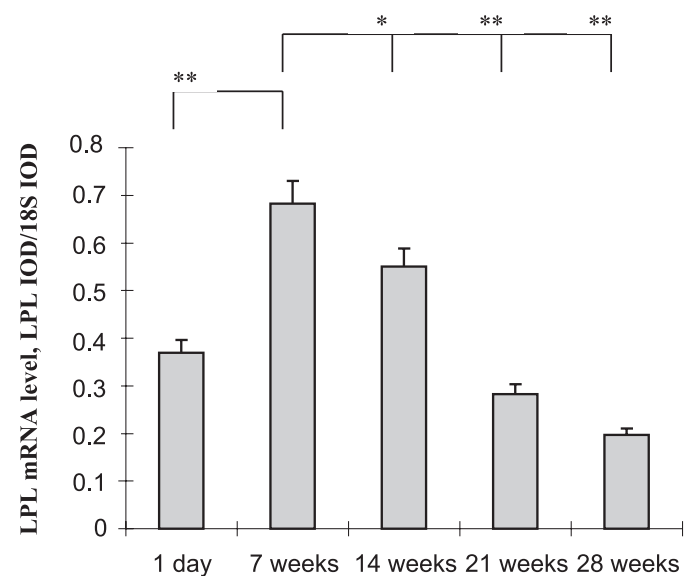

Figure 4. The mRNA levels of LPL in the subcutaneous adipose tissue of pigs aged at 1 day, 7, 14,21 and 28 weeks. The data showed the mean mRNA level of three pigs ( \pm SD) in each age as the ratio of the band intensity of each PCR product to the corresponding $18 \mathrm{~S}$ rRNA PCR product. $* \mathrm{P}<0.05, * * \mathrm{P}<0.01$

electrophoresis results of PCR products were shown in Figure 3, and the relative LPL mRNA levels were showed in Figure 4. As showed in Figure 4, the LPL mRNA was very low at birth (relative quantity was 0.37 ), and then significantly increased about $84.6 \%$ as compared with 1 -day-old pigs $(\mathrm{P}<0.01)$, reaching its maximal value at the age of 7 weeks, and gradually decreased from 7 to 28 weeks $(\mathrm{P}<0.01)$. And a significantly negative correlation between the mRNA level of LPL and age was found $(\mathrm{r}=-0.98, \mathrm{P}<0.01)$ between 7 weeks and 28 weeks.

\section{The relation between $L P L$ gene expression and adipose deposition}

The relative expression of LPL gene in subcutaneous adipose tissue increased significantly from 1 day to 7 weeks, then decreased (Figure 4). The body weight and adipose deposition increased significantly (Figures 1 and 2) with age from 1 day to 28 weeks. Correlation analysis showed that the relative expression of LPL was negative correlated with both the body weight $(\mathrm{r}=-0.97, \mathrm{P}<0.01)$ and adipose index $(\mathrm{r}=-0.94, \mathrm{P}<0.01)$ during growth between 7 and 28 weeks.

\section{DISCUSSION}

The effect of ages on the body weight and adipose deposition

Schwartz (1998) showed that aging in mammals is often associated with a relative increase in body adiposity and body weight. Middle-aged men had a 
higher percent body fat than young men (Imbeault et al., 2001). Aged mice exhibit an increase in their body weight, which is associated with fat deposit increase (Adachi et al., 1995).

In this study, we founded that the capacity of body weight and adipose index in pigs significantly increased with age between 1 day and 28 weeks $(\mathrm{P}<0.01)$. This result indicated that the body weight and the capacity of adipose deposition in pigs increased as they grew. This is consistent with previously published papers (Imbeault et al., 2000). Additionally, a strong positive correlation between age and adipose index as well as body weight in pigs between 1 day and 28 weeks were found. Previous study had proved that the fat content of the carcass was significantly correlated with animal age, and the fat percent in the carcass significantly increased from 16 to 25 weeks of age (Souza et al., 2004). Our work found that the adipose deposition was significantly correlated with pig age, and increased from 1 day to 28 weeks.

\section{Developmental gene expression of LPL in subcutaneous adipose tissue}

Previous studies have proved that aging have an effect on the expression of some genes expressed in adipose tissue (Hotta et al., 1999; Mooradian and Albert, 1999). Lipoprotein lipase cleaves fatty acids from the 1 and 3 position of the triacyglycerol molecule. Several studies have reported changes in LPL activity with ages (Mersmann, 1998), but no data about the LPL mRNA level.

This study evaluated LPL mRNA level of subcutaneous adipose tissue in pigs from 1 day to 28 weeks using semi-quantitative RT-PCR. The results showed that there are bi-phasic of changes in subcutaneous adipose tissue LPL mRNA level. The first phase, between 1 day to 7 weeks, is characterized by a positive correlation between LPL mRNA level and ages. The second phase, from 7 weeks to 28 weeks, is characterized by a strong negative correlation between LPL mRNA level and ages.

Hotta et al. (1999) found a decrease of LPL mRNA level in adipose tissue between young and old rhesus monkeys, and a significant negative correlation between age and the mRNA level of LPL, suggesting that the mechanism of regulation in adipose tissue with ageing involves a pretranslation process. In contrast, Bey et al. (2001) found that LPL mRNA concentration was not reduced in the muscle of old rats. Thus the effect of aging on the LPL mRNA level seems to be dependent on the tissues and animal species.

The relation between LPL gene expression and adipose deposition

Changes in adipose tissue metabolism may significantly contribute to the changes in body fat distribution. Adipose tissue lipoprotein lipase, responsible 
for the hydrolysis of circulating triglyceride into free fatty acids for uptake and storage by adipose tissue, plays a major role in accumulation and distribution of fat stores (Eckel, 1989). Previous studies demonstrated that LPL plays an important role in animals (Hocquette et al., 1998; Bonnet et al., 2000), and in ruminants at maintenance level, $55-60 \%$ of total amount of free acids originate from hydrolysis of circulating triacylglycerols by LPL (Pethick et al., 1993).

It has been reported that in bovine LPL gene expression levels in fats are an important index that is associated with body fat content, higher LPL gene expression in fat depots are correlated with the higher fat content in dairy cattle (Ren et al., 2002). Barber et al. (2000) reported that expression of the LPL gene in sheep was highly correlated with the size of adipocytes. Consistent with the previous studies, we found a significant positive correlation between the mRNA level of LPL and adipose deposition at the first phase in this experiment. However, a strong negative correlation between the LPL mRNA level and adipose deposition from 7 weeks to 28 weeks was also observed. These results suggest that the correlation between the LPL gene expression and adipose deposition could be affect by the animal species and animal ages. In addition, adipose tissue LPL expression was correlated with the adipose deposition, possibly indicating a functional coordination in the expression of this gene affecting lipid deposition in adipose tissue.

\section{CONCLUSIONS}

This study showed the developmental gene expression of LPL in adipose tissue at different ages and the relation with adipose deposition in pigs. The study of LPL, a key enzyme in lipid metabolism, could obtain information for novel approaches to regulate adipose deposition and meat production quality according to the developmental pattern of LPL gene expression in pigs.

\section{REFERENCES}

Adachi H., Kurachi H., Homma H., Adachi K., Tmai T., Sakata M., Matsuzawa Y., Miyake A., 1995. Invovement of epidermal growth factor in inducing adiposity of age female mice. J. Endocrinol. $146,381-393$

Barber M.C., Ward R.J., Richards S.E., Salter A.M., Buttery P.J., Vernon R.G., Travers M.T., 2000. Ovine adipose tissue monounsaturated fat content is correlated to depot-specific expression of the stearoyl-CoA desaturase gene. J. Anim. Sci. 78, 62-68

Bey L., Areiqat E., Sano A., Hamilton M.T., 2001. Reduced lipoprotein lipase activity in the postural skeletal muscle during aging. J. Appl. Physiol. 91, 687-692

Bonnet M., Leroux C., Faulconnier Y., Hocquette J.F., Bocquier F., Martin P., Chilliard Y., 2000. Lipoprotein lipase activity and mRNA are up-regulated by refeeding in adipose tissue and cardiac muscle of sheep. J. Nutr. 130, 749-756 
Eckel R., 1989. Lipoprotein lipase: a multifunctional enzyme relevant to common metabolic diseases. N. Engl. J. Med. 320, 1060-1068

Hocquette J.F., Graulet B., Olivecrona T., 1998. Lipoprotein lipase activity and mRNA levels in bovine tissues. Comp. Biochem. Physiol. Pt. B 121, 201-212

Hotta K., Bodkin N.L., Gustafson T.A., Yoshioka S., Ortmeyer H.K., Hansen B.C., 1999. Age-related adipose tissue mRNA expression of ADD1/SREBP1, PPARg, lipoprotein lipase, and GLUT4 glucose transporter in rhesus monkeys. J. Gerontol. A. Biol. Sci. Med. Sci. 54, 183-188

Imbeault P., Prudhome D., Tremblay A., Despres J.P., Mauriege P., 2000. Adipose tissue metabolism in young and middle-aged men after control for total body fatness. J. Clin. Endocrinol. Metab. $85,2455-2462$

Imbeault P., Vidal H., Tremblay A., Vega N., Nadeau A., Despres J.P., Mauriege P., 2001. Agerelated differences in messenger ribonucleic acid expression of key proteins involved in adipose cell differentiation and metabolism. J. Clin. Endocrinol. Metab. 86, 828-833

Maingrette F., Renier G., 2003. Leptin increases lipoprotein lipase secretion by macrophages: Involvement of oxidative stress and protein kinase C. Diabetes 52, 2121-2128

Marone M., Mozzetti S., Ritis D.D., Pierelli L., Scambia G., 2001. Semiquantitative RT-PCR analysis to assess the expression levels of multiple transcripts from the same sample. Biol. Procedures Online 3,19-25

Merkel M., Eckel R.H., Goldberg I.J., 2002. Lipoprotein lipase: genetics, lipid uptake, and regulation. J. Lipid Res. 43, 1997-2006

Mersmann H.J., 1998. Lipoprotein and hormone-sensitive lipase in porcine adipose tissue. J. Anim. Sci. 76, 1396-1404

Mooradian A.D., Albert S.G., 1999. The age-related changed in lipogenic enzyme: the role of dietary factors and thyroid hormone responsiveness. Mech. Age. Dev. 108, 139-149

Nogalska A., Swierczynski J., 2001. The age-related differences in obese and fatty acid synthase gene expression in white adipose tissue of rat. Biochim. Biophys. Acta 1533, 73-80

Pethick D.W., Dunshea F.R., 1993. Fat metabolism and turnover. In: J.M. Forbes, J. France (Editors). Quantitative Aspects of Ruminant Digestion and Metabolism. CAB International Press, Wallingford, pp. 291-311

Ren M.Q., Wegner J., Bellmann O., Brockmann G.A., Schneider F., Teuscher F., Ender K., 2002. Comparing mRNA levels of genes encoding leptin, leptin receptor, and lipoprotein lipase between dairy and beef cattle. Domest. Anim. Endocrinol. 23, 371-381

SAS, 1989. SAS User's Guide. SAS Institute Inc., Cary, NC

Schwartz R.S., 1998. Obesity in the elderly. In: G.A. Bray, C. Bouchard, W.P.T. James (Editors). Handbook of Obesity. Marcel Dekker, Inc. New York, pp. 103-114

Souza D.N., Pethick D.W., Dunshea F.R., Suster D., Pluske J.R., Mullan B.P., 2004. The pattern if fat and lean muscle tissue deposition differs in the different pork primal cuts of female pigs during the finisher growth phase. Livest. Prod. Sci. 91, 1-8

Taylor B.A., Phillips S.J., 1996. Detection of obesity QTLs on mouse chromosomes 1 and 7 by selective DNA pooling. Genomics 34, 389-398

Ursini F., Vugman M., Fernandes L.C., Curi C., Curi R., 1991. Metabolic changes of several adipose depots as caused by aging. Physiol. Behav. 50, 317-321 